\title{
STRATEGIC MODULATION OF THERMAL TO ELECTRICAL ENERGY RATIO PRODUCED FROM PV/T MODULE
}

\author{
Anges A. Aminou Moussavou*, Atanda K. Raji, Marco Adonis \\ Center for Distributed Power and Electronics Systems, Cape Peninsula University of Technology (Bellville \\ Campus), Department of Electrical Engineering, Symphony Way, PO Box 1906, Bellville 7535, South Africa \\ * corresponding author: akdech80@yahoo.fr
}

\begin{abstract}
Several strategies have been developed to enhance the performance of a solar photovoltaicthermal $(\mathrm{PV} / \mathrm{T})$ system in buildings. However, these systems are limited by the cost, complex structure and power consumed by the pump. This paper proposes an optimisation method conversion strategy that modulates the ratio of thermal to electrical energy from the photovoltaic (PV) cell, to increase the PV/T system's performance. The design and modelling of a PV cell was developed in MATLAB/Simulink to validate the heat transfer occurring in the PV cell model, which converts the radiation (solar) into heat and electricity. A linear regression equation curve was used to define the ratio of thermal to electrical energy technique, and the behavioural patterns of various types of power (thermal and electrical) as a function of extrinsic cell resistance $\left(R_{s e}\right)$. The simulation results show an effective balance of the thermal and electrical power when adjusting the $R_{s e}$. The strategy to modulate the ratio of thermal to electrical energy from the PV cell may optimise the PV/T system's performance. A change of $R_{s e}$ might be an effective method of controlling the amount of thermal and electrical energy from the PV cell to support the PV/T system temporally, based on the energy need. The optimisation technique of the PV/T system using the PV cell is particularly useful for households since they require electricity, heating, and cooling. Applying this technique demonstrates the ability of the PV/T system to balance the energy ( thermal and electrical) produced based on the weather conditions and the user's energy demands.
\end{abstract}

KEYwords: Cell efficiency, photovoltaic systems, solar photovoltaic-thermal (PV/T) system, modelling and simulation, power production.

\section{INTRODUCTION}

Renewable energy (RE) originates from the natural processes, which are constantly replenished [1]. RE has been widely promoted in many countries to mitigate the use of electricity from the main grid [2, 3]. $\mathrm{RE}$ prevails over fossil fuels because of the high price of oil. Furthermore, it is less harmful to the environment as compared to the traditional power plant [4, 5]. From all the different forms of renewable energy, solar radiation can be used to generate electricity and heat. It offers a sustainable energy supply to domestic and industrial sectors and has demonstrated a promising energy economic development [6, 7].The combination of photovoltaic and thermal $(\mathrm{PV} / \mathrm{T})$ systems is used to generate electricity and thermal energy. The inclusion of the $\mathrm{PV} / \mathrm{T}$ system in buildings can achieve substantial energy-savings.

Studies on the efficiency of domestic hot water (DHW) distribution systems in buildings have shown that the innovative circulation pipes improve the DHW by reducing the losses by $40 \%$ [8]. However, it has been acknowledged that the action of cooling and reheating water in pipes may lead to a thermal fatigue of fixtures and reduce their life cycle $[9,10]$.

An improvement of the PV/T system composed of PV laminate and absorber with two water channels in which water flows through the upper channel and returns through the lower channel was reported [11. [12. This system presents a high thermal efficiency; however, the geometric complexity makes it difficult to manufacture. A conceptual nanofluid-based PV/T system was developed to improve the thermal and electrical efficiency of the system. It was noted that at a temperature of about $62{ }^{\circ} \mathrm{C}$, the controlled flow rate of the nanofluid yielded a total efficiency of $70 \%$, while the electrical and the thermal efficiency were $11 \%$ and $59 \%$, respectively [13]. However, this method is costly, suffers from the high-pressure drop and is difficult to hold nanoparticles suspended in the base liquid [14, 15].

An environmentally friendly PV/T system was proposed using a glazed solar collector composed of a PV panel bonded to a metal absorber [16]. The experimental results obtained from the proposed $\mathrm{PV} / \mathrm{T}$ system show that the PV panel temperature was $45^{\circ} \mathrm{C}$, even in summer, the water temperature circulating within the $\mathrm{PV} / \mathrm{T}$ was $60^{\circ} \mathrm{C}$ based on the flow rate control [16]. A feasibility study of using the PV/T optimisation as a heat source and sink for a reversible heat pump to cool and heat the standard building in three distinct climate zones was evaluated. This $\mathrm{PV} / \mathrm{T}$ system proved to be technically feasible, and its yearly costs are relatively similar to the traditional 
solar cooling systems that use a reversible air-to-water heat pump as the heat and cold source [17.

In view of these findings, it is obvious that an improvement of the $\mathrm{PV} / \mathrm{T}$ system's performance is needed. This paper proposes an optimisation technique of the PV/T system's performance using the heat flow from the PV cell. Therefore, a controllable self-heating (useful heat) PV cell model using an external parameter is developed to support the $\mathrm{PV} / \mathrm{T}$ system. The PV cell is partially turned into a useful heat source. Modelling and analysing the PV cell as well as thermal power, electrical power and energy efficiency, were evaluated.

\section{TheORETICAL ANALYSis OF PHOTOVOLTAIC MODULES}

Solar photovoltaic technology is highly appreciated due to its abundance and environmental friendliness as compared to other sources. The PV module performance characteristics mainly depend on the ambient temperature and solar radiation. Also, it depends on parameters such as local wind speed, the material and structure of the photovoltaic module, such as glazing-cover transmittance and absorbance [18, 19]. These parameters have an impact on the low energy efficiency conversion.

\subsection{INFLUENCE OF SOLAR RADIATION}

The overall photovoltaic module performances are typically defined by the standard test conditions (STC), such as radiation, which is $1000 \mathrm{~W} / \mathrm{m}^{2}$, ambient temperature, $25^{\circ} \mathrm{C}$, air mass is 1.5 . There is no air velocity near the PV module. However, these performances are completely different once operating in real-world conditions; this difference is due to the perpetual change of the conditions. The PV module performance is associated with the absorption of the solar radiation, the position of the sun through each day and the apparent sun movement during the year [20. Solar radiation does not reach the Earth's surface intact, because it passes through the Earth's atmosphere. The luminous intensity and its spectrum depend not only on the composition of the atmospheric particles and gases but also on clouds [21-23]. The impact of irradiance on the PV module is given in Equation 1

$$
I_{s c}(T)=I_{s c, r e f}[1+\alpha(T-25)] \frac{G}{1000 \mathrm{~W} / \mathrm{m}^{2}}
$$

Where $I_{s c, r e f}, G, \alpha$ and $T$ represent the reference short-circuit current at $25^{\circ} \mathrm{C}$, global solar radiation on the photovoltaic module surface $\left(\mathrm{W} / \mathrm{m}^{2}\right)$, a constant temperature coefficient of the module, and the temperature of the photovoltaic module Kelvin (K), respectively.

Photovoltaic modules are made to convert solar radiation into electrical energy. Figure 1 illustrates the influence of the irradiation intensity variation on the PV modules. Figure 1 shows that when the solar

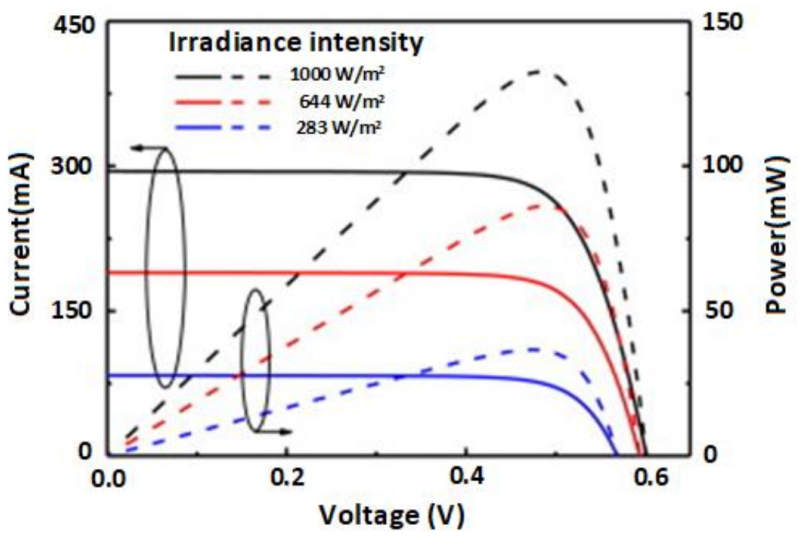

Figure 1. The PV cell's characteristics under various solar radiation 24 .

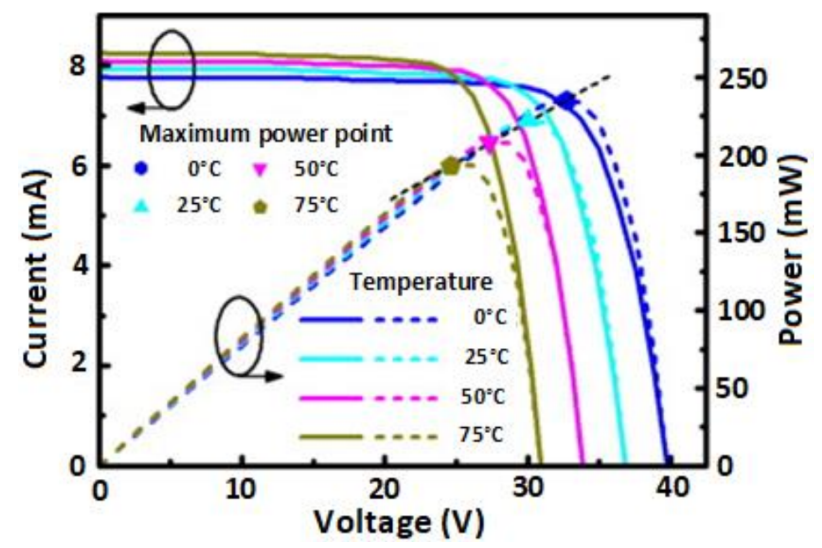

Figure 2. The PV module characteristics under various temperatures and an irradiation intensity of $1000 \mathrm{~W} / \mathrm{m}^{2}$ [25].

radiation increases from 233 to $1000 \mathrm{~W} / \mathrm{m}^{2}$, the maximum power increases from 30 to $120 \mathrm{~mW}$, respectively. The open-circuit voltage of the PV module increases by $0.05 \mathrm{~V}$, while the current stays constant [21, 24].

\subsection{INFLUENCE OF THE OPERATING TEMPERATURE OF THE PV MODULE}

The temperature rise of the photovoltaic (PV) module reduces its open-circuit voltage $\left(V_{o c}\right)$ and decreases the maximum power $\left(P_{m p}\right)$. At high temperatures, the formation of electron-holes and the bandgap of the photovoltaic module decreases, while the dark current saturation increases [27 29]. Figure 2 illustrates the $I-V$ characteristics curve of the Photovoltaic performance. The $V_{o c}$ dependence on $T$ is given by the equation below.

$$
V_{o c}(T)=V_{o c, r e f}\left[1+\beta\left(T_{c}-T_{r e f}\right)\right]
$$

Where $V_{o c, r e f}, \beta, T_{r e f}$ and $T_{c}$ represent the reference of the open-circuit voltage, temperature coefficient, the operating temperature of the module and the reference temperature at $25^{\circ} \mathrm{C}$, respectively. The derivative of $V_{o c}$ with respect to the temperature and energy 


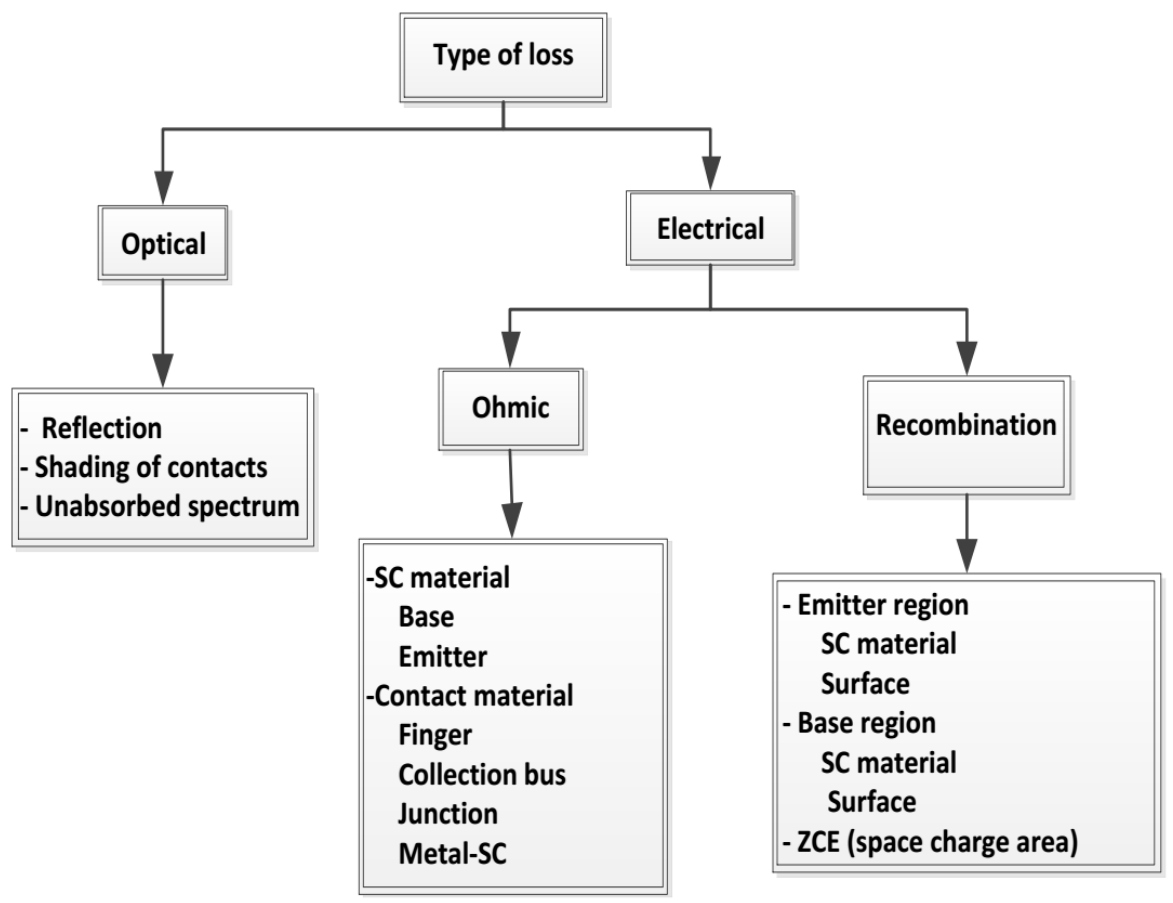

Figure 3. Different sources of losses [26].

gap of the semiconductor is expressed in Equation 3

$$
\begin{aligned}
V_{o c}(T) \frac{d V_{o c}}{d T}=\frac{V_{o c}}{T}- & \frac{\gamma k}{q}-\frac{E_{g 0}}{q T}= \\
& =\frac{1}{T}\left(V_{o c}-\frac{E_{g 0}}{q}\right)-\frac{\gamma k}{q}
\end{aligned}
$$

Where $\gamma, k, E_{g 0}$ and $q$ represent the specifics of the temperature coefficient, Boltzmann constant, band gap of the material and electron charge $(\mathrm{C})$, respectively.

The photovoltaic module defined parameters are maximum voltage, open-circuit voltage, maximum current, short-circuit current, maximum power, fill factor and efficiency. In Figure 2, it is denoted that when the temperature increases from 0 to $75^{\circ} \mathrm{C}$, as an immediate consequence, the open-circuit voltage of the photovoltaic module decreases from 40 to $31 \mathrm{~V}$, the maximum power point declines by $55 \mathrm{~W}$ and the short-circuit current increases slightly by $0.3 \mathrm{~A}[30-32$. It is also observed that temperature variations have a marginal effect on the $I_{s c}$, while having a substantial impact on $V_{o c}$ 28, 33. The characteristics curve is influenced to different values when photovoltaic modules are exposed to cell damage, radiation change, temperature inequality, local shading and dust, which considerably decreases the output power 3032 .

\subsection{LOSSES DUE TO EXTRINSIC AND INTRINSIC} IN A SOLAR CELL

Different power losses occur in the PV cell and can be categorised as extrinsic and intrinsic losses, and optical and electrical losses [26, 34 as shown in Figure 3 .

Extrinsic loss: This type of losses is caused by reflection, cell damage, shading, series resistance, radiation change, incomplete collection of generated photocarriers, absorption in the window layer and non-radiative recombination. If the $\mathrm{PV}$ module operates under partial shading, the shadow cell is reversely polarised and amplified in the opposite direction; this produces high temperatures because it is charged 35 37.

Intrinsic losses: This type of losses is caused by two factors and the lack of ability of the single-junction solar cell to react adequately to all wavelength spectrums. The solar cell becomes translucent to the photon energy $(E p h)$, and this energy is less than the band gap energy $(E g)$ of the semiconductor $(E p h<E g)$. However, on condition that the photon energy is higher than the band gap energy of the semiconductor $(E p h>E g)$, the extra energy is dissipated in the form of heat. The loss is also due to the radiative recombination in the solar cell. The common semiconductor material used for the solar cell is silicon, monocrystalline, polycrystalline and amorphous with an efficiency of $20 \%, 12 \%$ and $7 \%$, respectively [38. The solar cell heating is reversely proportional to the efficiency [29.

\section{Method AND Simulation SET UP}

The simulation predicts the thermal behaviour patterns, the total power dissipated $(P d)$, the power generated and the effectiveness of the PV cell model. This $\mathrm{PV}$ model comprises a diode (made of the semiconductor property material of the photovoltaic cell), internal series and internal parallel resistance. It should be noted that for a simulation of a physical phenomenon, like the issue of heat transfer, in Simulink/Simscape, there is a need to establish the calculations of the heat 


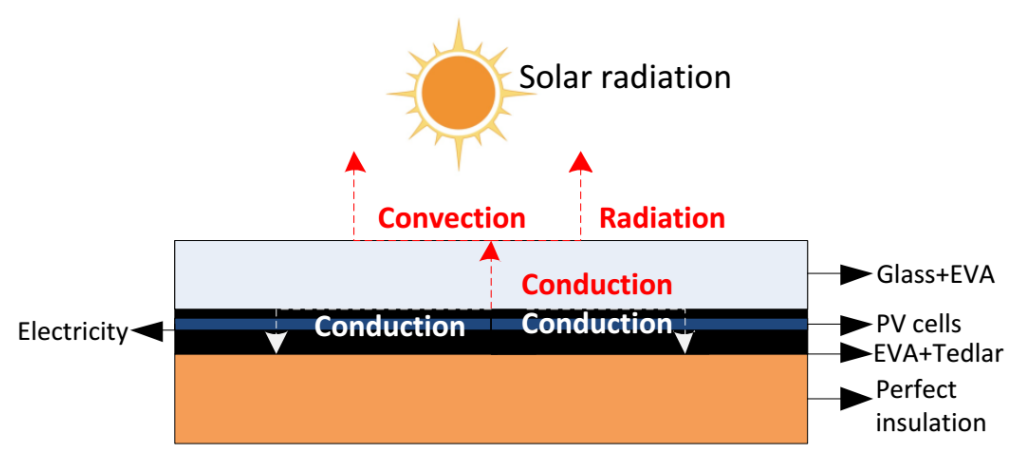

FiguRE 4. Heat transfer characteristics of the PV system.

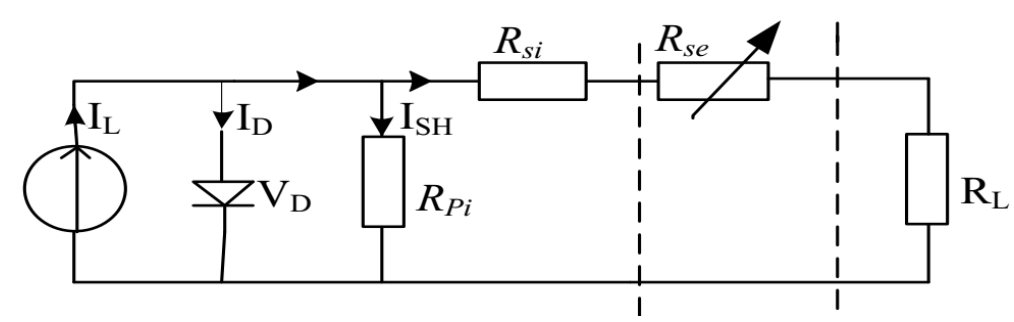

FiguRE 5. Evaluation of PV performance under extrinsic cell resistance.

transfer occurring in this study. Figure 4 depicts the heat transfer characterisation of the PV system.

The following section evaluates the distribution of power dissipated in the PV cells, triggered by extrinsic cell resistance $\left(R_{s e}\right)$. For this, the electro-thermoradiative behaviour pattern of the PV cell, for various values of $R_{\text {se }}$ ranging from 0 to $100 \Omega$, were simulated while maintaining other parameters, such as solar radiation at $1000 \mathrm{~W} / \mathrm{m}^{2}$, ambient temperature at $20^{\circ} \mathrm{C}$ and convective heat transfer at $\left.20 \mathrm{~W} /\left(\mathrm{m}^{2} \cdot \mathrm{K}\right)\right)$.

The extrinsic cell resistance $\left(R_{s e}\right)$ is illustrated in Figure 5 . The value of $R_{\text {se }}$ can be obtained analogically with a variable resistance. It can also be obtained electronically by applying a voltage on the FET's gate pin resistance. The channel resistance of the FET is a function of the gate-source voltage. By increasing the reverse biasing, the resistance increases.

In this study, the PV modules parameters are listed in Table 1 and Table 2. The entire PV system consists of two PV arrays assumed to perform identically and in a parallel configuration; the system has a capacity of $3.24 \mathrm{~kW}_{\mathrm{p}}$ at $1000 \mathrm{~W} / \mathrm{m}^{2}$.

\section{Simulation Results AND DISCUSSION}

The PV cell model is analysed and discussed to better appreciate the optimisation technique of the $\mathrm{PV} / \mathrm{T}$ system using the PV cell. The simulation is performed under stable conditions.

\subsection{PV CELL POWER DISSIPATION AS A FUnCTION OF $R_{\text {se }}$}

The parameters representing the PV cell's internal properties are comprised of a diode, series resistance and parallel resistance. The model is assessed based on extrinsic cell resistance. Figure 6 shows an increment in the total $P d$ curve, from 990 to $3490 \mathrm{~W}$, as $R_{\text {se }}$ increases. Series resistance marginally increases, while parallel resistance remains virtually the same. A considerable amount of the total power dissipation is attributed to the diode (because of the recombination current of the semiconductor material property used to make the PV cell model), ranging from 750 to $3480 \mathrm{~W}$. The series and parallel resistance resistivity losses decrease as less current flow through them.

A substantial reverse current occurred in the PV cells in the form of heat. This reverse current leads to a $P d$ and then to a local overheating and turns into heat by conduction. The PV thermal resistance varies based on the width of the material and its thermal resistivity. Figure 6 shows an increase in the total $P d$ of the PV cell, from 990 to $3490 \mathrm{~W}$, as $R_{\text {se }}$ increases. This increase in $R_{s e}$ will reduce the fill factor and then decrease the maximum-power point of PV cells. The graph in Figure 6 is consistent with those obtained from previous studies 3941 . However, here, the $R_{\text {se }}$ causes the restricted conductivity of the terminal material used. The following trend can be elucidated: the $R_{s e}$ constrains a partial conversion of the PV output into a useful thermal energy. This study focuses on the internal heat generation and electrical power generation of the PV cell based on the $R_{s e}$. The technique relies on the linear regression equation curve to model the behaviour of different types of power as a function of $R_{s e}$ in the $\mathrm{PV}$ cell being studied. 


\begin{tabular}{clc}
\hline Component & Parameter & Value \\
\hline PV modules & Cell type & Mono-crystalline \\
& Packing factor & 0.91 \\
& Conversion efficiency & $16 \%$ \\
& Module peak power & $3.25 \mathrm{~kW}$ \\
& Maximum voltage, $V_{m}$ & $255 \mathrm{~V}$ \\
& Maximum current, $I_{m}$ & $12.4 \mathrm{~A}$ \\
& Open circuit voltage, $V_{o c}$ & $310 \mathrm{~V}$ \\
& Short circuit current, $I_{s c}$ & $14.64 \mathrm{~A}$ \\
& Series resistance $R_{s i} /$ cell & $0.0042 \Omega$ \\
& Parallel resistance $R_{p i} /$ cell & $10.1 \Omega$ \\
\hline
\end{tabular}

TABLE 1. PV module parameters.

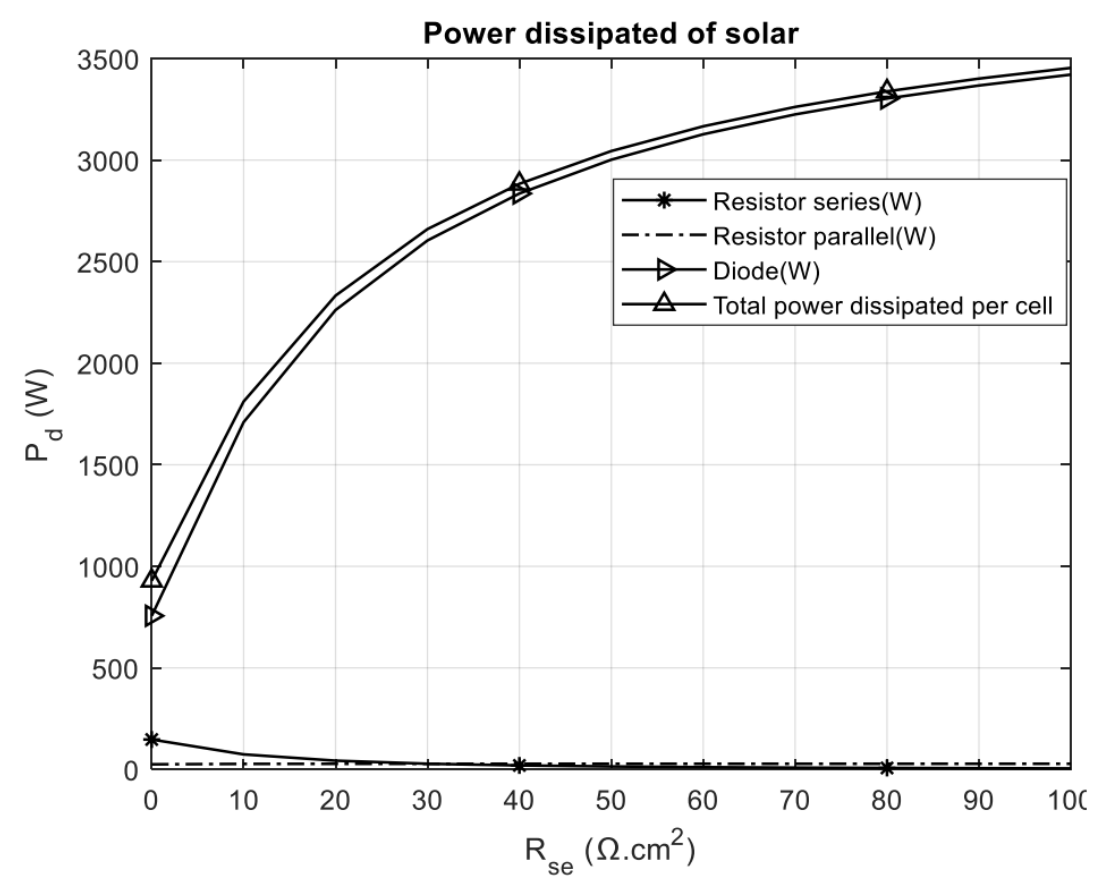

Figure 6. Dissipated power by PV cell versus $R_{s e}$.

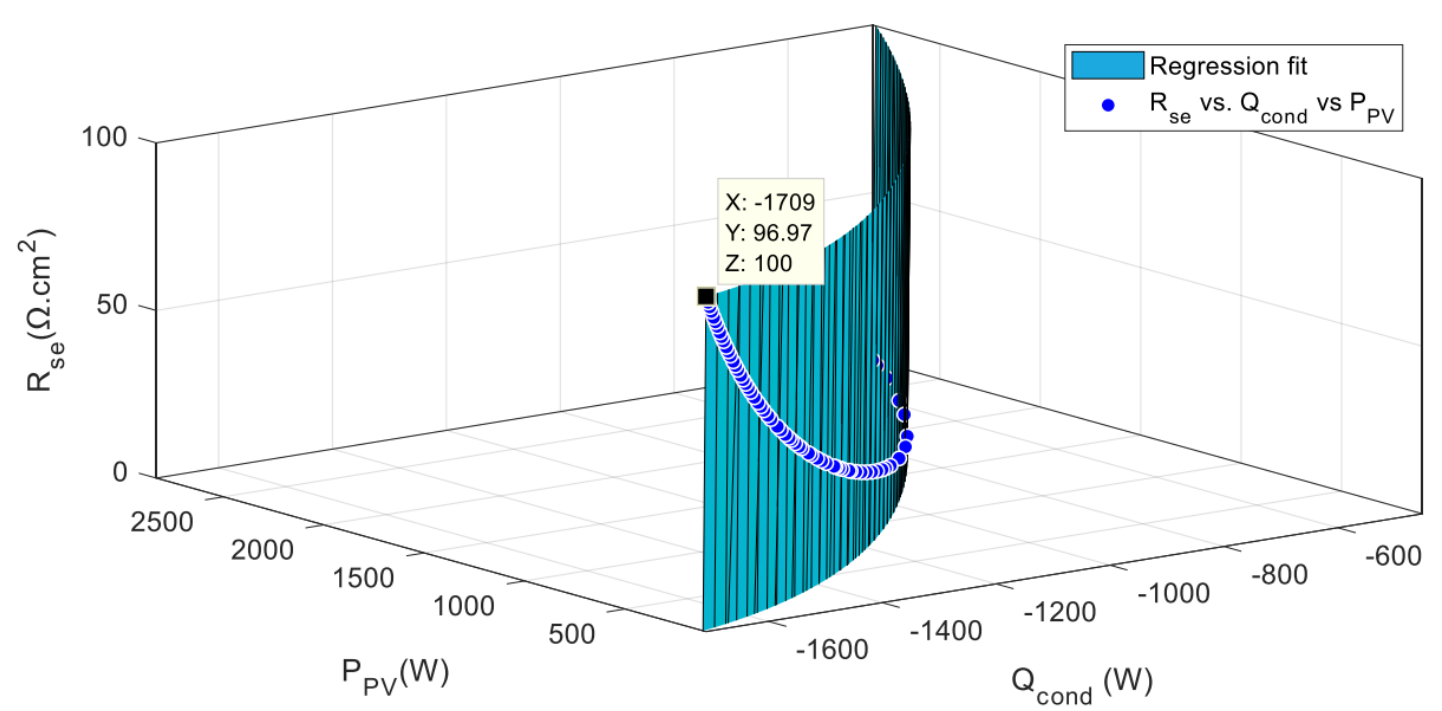

Figure $7 . R_{s e}$ according to the power generated and heat by conduction of the PV module. 


\begin{tabular}{lc}
\hline & PV module type \\
\hline Absorbance $\alpha$ & 0.8 \\
Emissivity $\epsilon$ & 0.75 \\
Thermal conductivity & 840 \\
Thickness $\delta$ & 0.003 \\
Temperature coefficient & 0.000905 \\
Energy gap $E G$ & 1.11 \\
\hline
\end{tabular}

TABLE 2. Optical parameters of PV cells.

\subsection{ESTIMATION OF HEAT TRANSFER BY CONDUCTION AND GENERATED PV POWER AS A FUnCTION OF $R_{s e}$}

The synthesis of the results, illustrated in Figure 7 in $3 \mathrm{D}$, shows a standardised map of $R_{\text {se }}$ as a function of the heat transfer by conduction, and the generated PV power. The normalised yields are plotted on this map, which includes the polynomial surface of the model. By adjusting $R_{\text {se }}$, the equivalent values of the electrical power generated and electrical power dissipated by heat conduction is determined. Figure 7 presents the heat generated by conduction $\left(Q_{\text {cond }}\right)$ within the PV cell. $Q_{\text {cond }}$ rises from 425 to $1715 \mathrm{~W}$ (in magnitude) as $R_{\text {se }}$ moves from 0 to $100 \Omega$. This heat is ascribed to electrical power dissipated in the $\mathrm{PV}$ cell, and part of the dissipated power turns into useful energy within the PV cell. However, the temperature difference is the main impetus behind the conductive heat flow in a material with a given thermal resistance, and the transfer is governed by the Fourier law.

It can be seen in Figure 7 that the generated PV power decreases as $R_{\text {se }}$ increases. The power rapidly (exponentially) falls from $2800 \mathrm{~W}$ to $260 \mathrm{~W}$ when $R_{\text {se }}$ increases from 0 to $50 \Omega$, and beyond $50 \Omega$, the power decreases slower from $255 \mathrm{~W}$ to $110 \mathrm{~W}$. The power degradation of a PV cell is due to recombination according to $R_{s e}$ variation, leading to electrical power dissipation in the form of heat by conduction. These outcomes are in concurrence with those acquired by other authors, where the rise of $R_{s e}$ is attributed to dust particles on the PV model [42 44]. Contrary to other studies, $R_{s e}$ is used to proportionally influence the electrical power and power dissipation of the PV cell.

A polynomial model appropriately represents the graphical model of the results. It can be used to predict and interpret the PV cell's performance. The confidence intervals and the means of the linear regression equation for the graphical model result was derived. The estimation graph is expressed by Equation 4

$$
\begin{aligned}
& R_{\text {se }}\left(Q_{\text {cond }} P_{P V}\right)=p 00+p 10 \cdot Q_{\text {cond }}+p 01 \cdot P_{P V}+ \\
& +p 20 \cdot Q_{\text {cond }}^{2}+p 11 \cdot Q_{\text {cond }} \cdot P_{P V}+p 02 \cdot P_{P V}^{2}
\end{aligned}
$$

where $p 00, p 10, p 01, p 20, p 11$ and $p 02$ are coefficients, $Q_{\text {cond }}$ is the thermal transfer coefficient by conduc- tion (W), $P_{P V}$ is the generated $\mathrm{PV}$ power and $R_{\text {se }}$ is the external series resistance $(\Omega)$.

Table 3 describes the polynomial interpretation of the surface plot result of the heat conduction and PV power as a function of $R_{\text {se }}$ in Figure 7, The estimation curve is expressed by Equation 4 To find the optimal power (electrical or thermal), computation of the coefficient of determination $\left(R^{2}\right)$ is 0.9998 and RMSE is 0.4791 for any selected value of $R_{\text {se }}$.

\subsection{CONVECTION AND RADiATION HEAT GENERATED BY THE PV CELL}

Figure 8 illustrates a steady increase in convection $\left(Q_{\text {conv }}\right)$ from $3100 \mathrm{~W}$ to $5300 \mathrm{~W}$ when the $R_{\text {se }}$ value increases from 0 to $100 \Omega$, as the heat is carried to the atmosphere. The impact of heat on the PV cell is caused by the high electrical power dissipation, and the heat loss by the conduction happening in the PV cell. The thermal loss by $Q_{\text {conv }}$ increases faster when $R_{\text {se }}$ is in the range between 0 and $50 \Omega$; nonetheless, $Q_{\text {conv }}$ is slowed down and approaches saturation when $R_{s e}$ is higher than $50 \Omega$

Figure 9 presents the incremental change of radiation $\left(Q_{\text {rad }}\right)$ from $350 \mathrm{~W}$ to $660 \mathrm{~W}$ when $R_{\text {se }}$ increases from 0 to $100 \Omega$. The PV cell emits radiation based on its temperature. Also, the losses depend on the absorptivity of the covering glass.

The outcomes shown in Figure8 and Figure 9 demonstrate that the growth of the heat loss by $Q_{c o n v}$ is higher than that in $Q_{\text {rad }}$. Both were assessed as positive values, which shows that they are taken away into the ambient environment. At the same time, the $Q_{\text {cond }}$ is measured as a negative value in Figure 7 This negative value indicates that the $Q_{\text {cond }}$ is directed mostly inside the PV cell. Comparing the heat transfer happening in the $\mathrm{PV}$ cell, $Q_{\text {conv }}, Q_{\text {cond }}$ and $Q_{\text {rad }}$, varied by $2200 \mathrm{~W}, 1290 \mathrm{~W}$ and $310 \mathrm{~W}$, respectively, as $R_{s e}$ differed by $100 \Omega$. Some others discussed the convection, conduction and radiation heat transfer occurring in the PV module, here, the effect of $R_{s e}$ is included in this paper [45,48].

\subsection{The PV CELL TEMPERATURE UNDER $R_{s e}$ VARIATION}

Figure 10 illustrates the logarithmic growth of Tc as a function of $R_{s e}$. As $R_{s e}$ varies from 0 to $50 \Omega$, the temperature Tc rises from 45 to $59{ }^{\circ} \mathrm{C}$, and as $R_{\text {se }}$ value increases from 50 to $100 \Omega$, Tc increases slowly from 59 to $62^{\circ} \mathrm{C}$. The rise in Tc leads to a build-up of electrical $P d$ in the form of heat in Figure6 6 . Most of the previous works show that the $R_{s e}$ expands by the rise of the PV cell temperature [41. Inversely, here, the PV cell temperature is controlled by $R_{s e}$, to improve the PV/T system's thermal efficiency.

\subsection{PV CELL ELECTRICAL EFFICIENCY UNDER $R_{s e}$ VARIATION}

Figure 11 presents the PV cell electrical efficiency dependence on $R_{s e}$. The PV cell electrical efficiency 


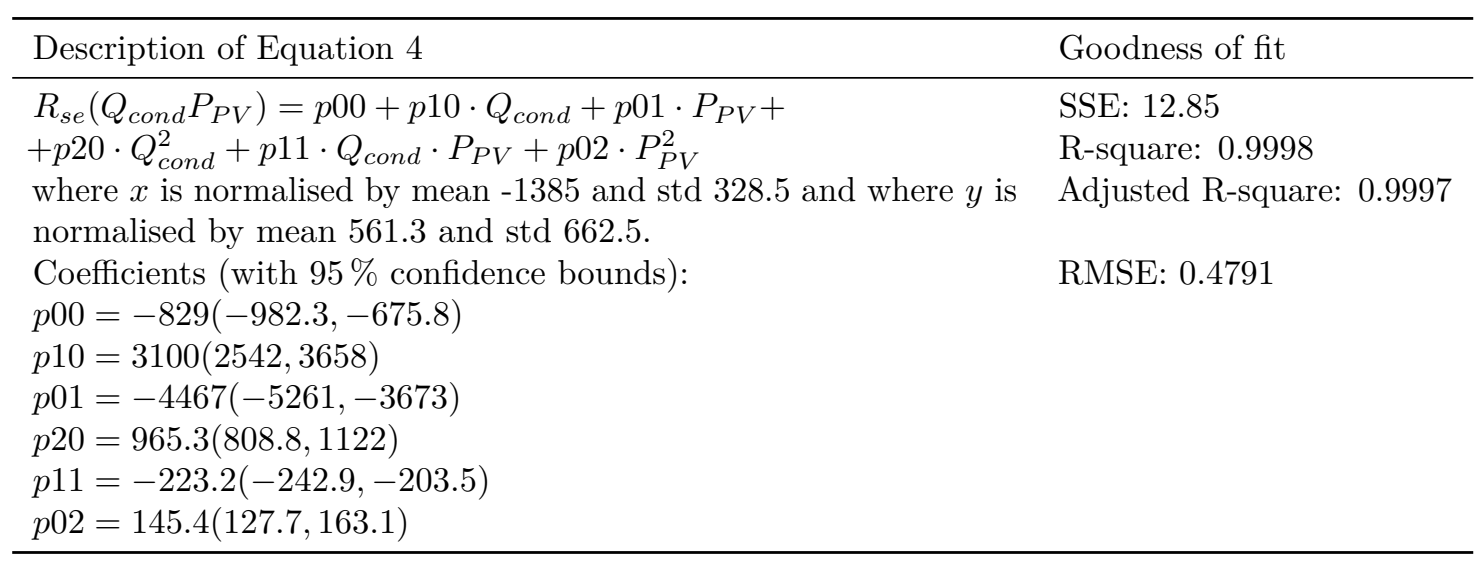

TABle 3. Linear model Poly22 of Figure 7

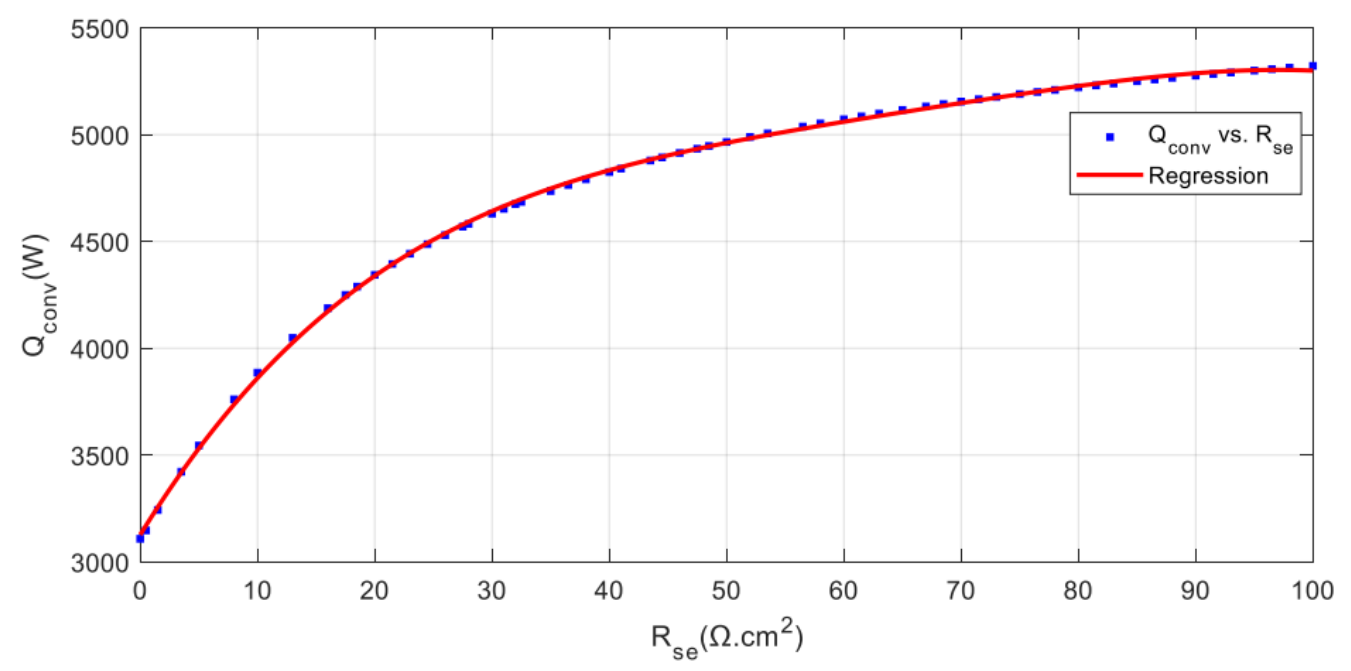

Figure 8. Convection heat transfer versus $R_{s e}$.

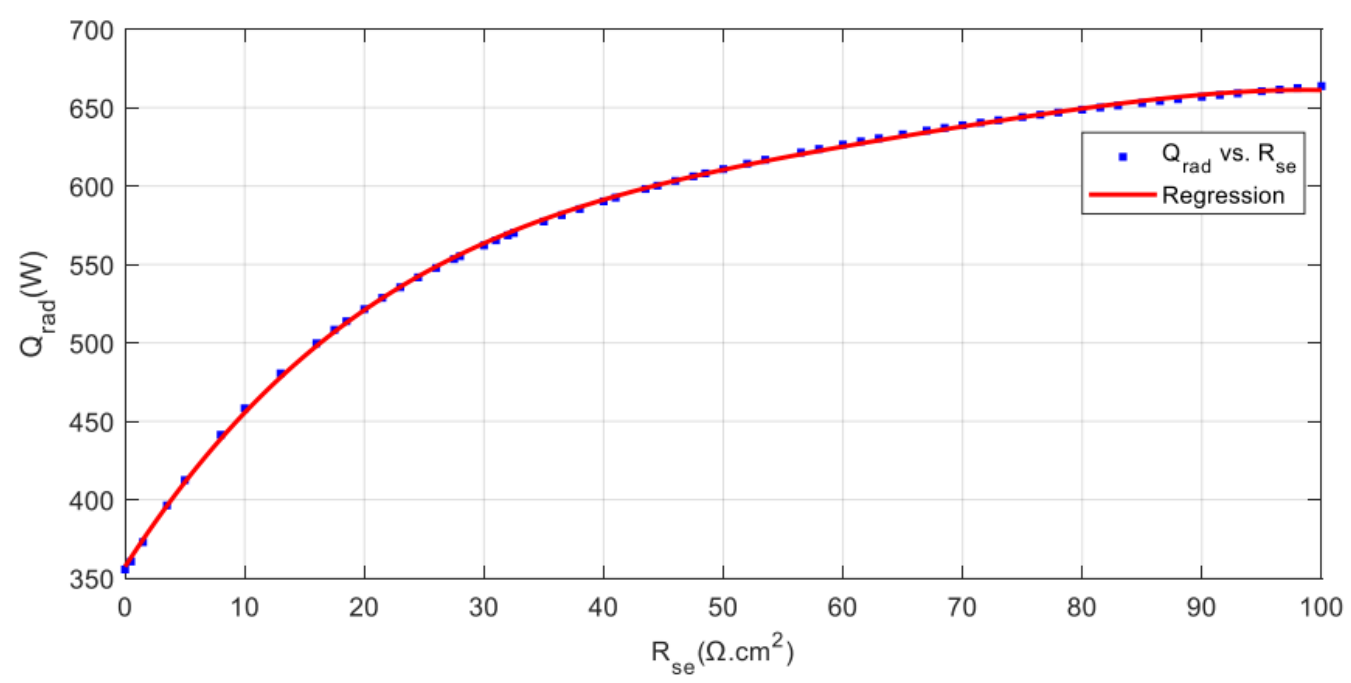

FiguRE 9. Radiation heat transfer versus $R_{s e}$. 


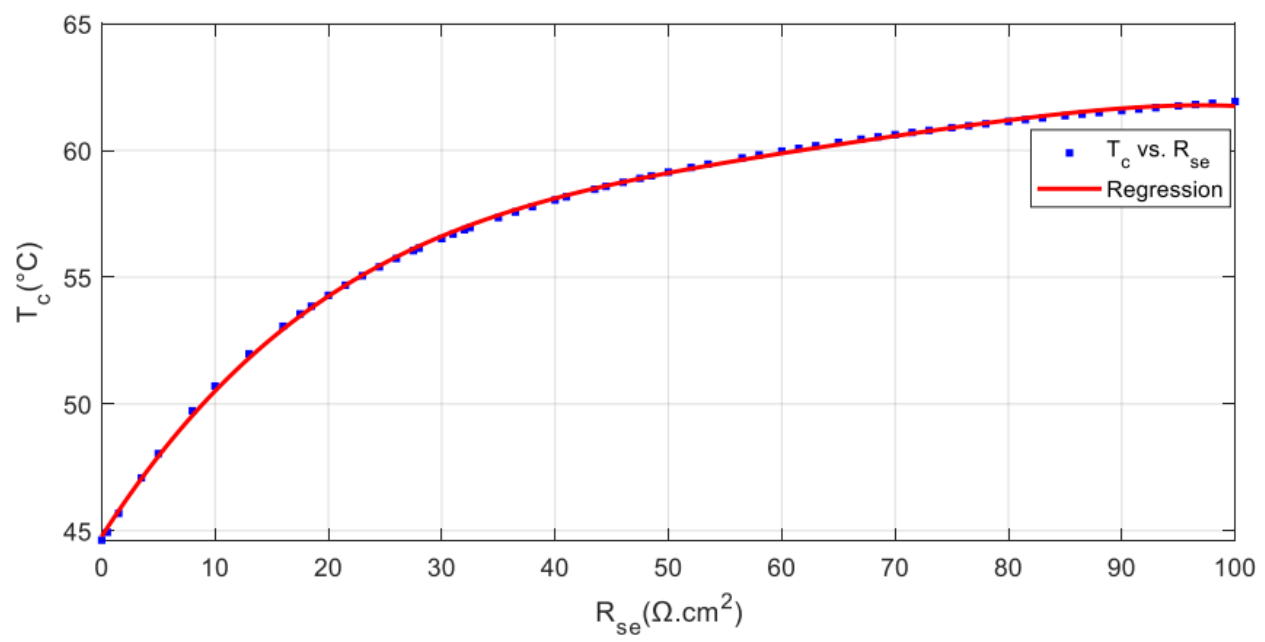

Figure 10. PV cell temperature versus $R_{s e}$.

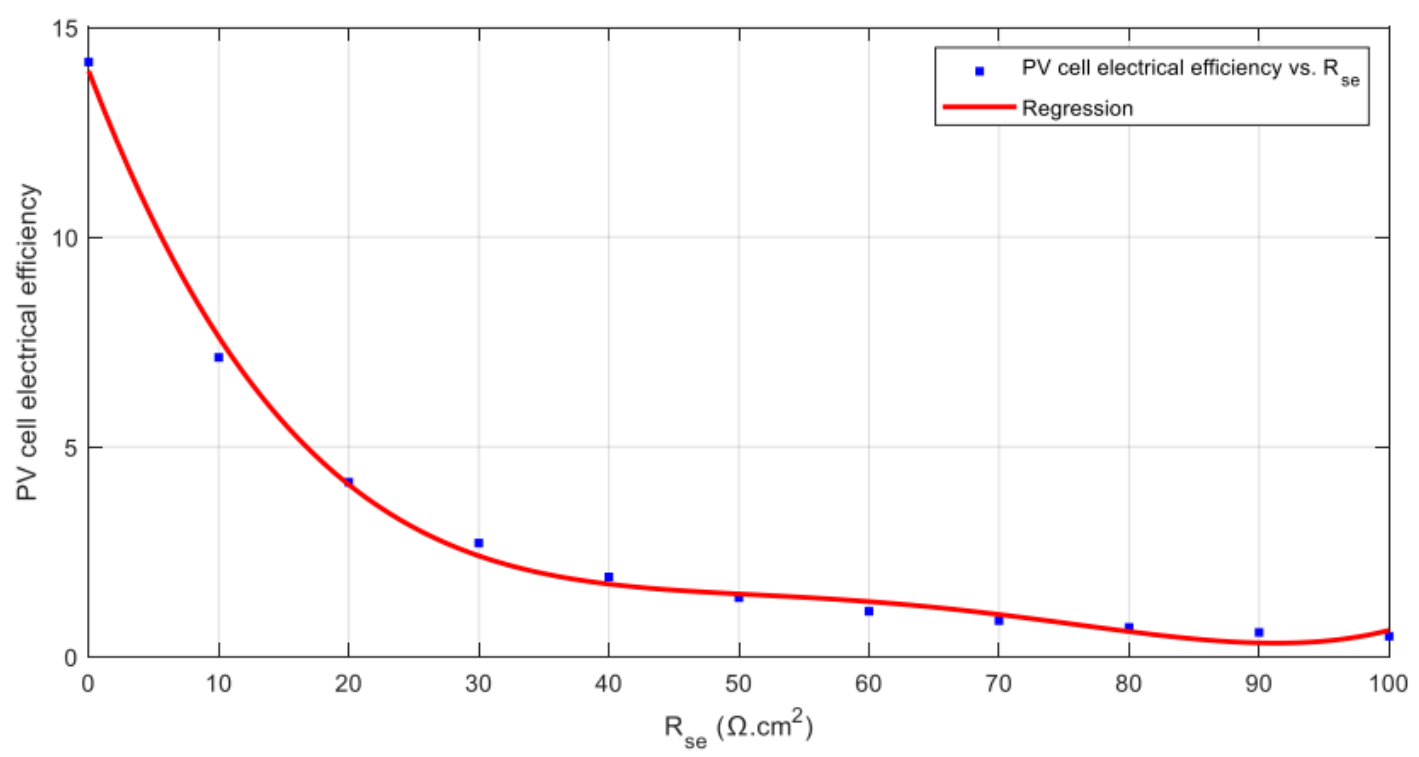

Figure 11. PV cell electrical efficiency dependence on $R_{s e}$.

quickly (exponentially) falls from $14.2 \%$ to $2.5 \%$ when Rs increases from 0 to $50 \Omega$, and above $50 \Omega$, the efficiency slowly decreases from $2.5 \%$ to $1.5 \%$. This was observed to be in agreement with the results reported by similar studies [41, 49]. The degradation of the PV cell power was due to the power dissipation in the form of heat shown in Figure 6

\subsection{Generated power through time}

Here, the heat by conduction corresponds to the useful thermal energy. In the electrical power and the heat by conduction in the PV module vary based on $R_{s e}$, mainly due to the power dissipation.

Here, the heat by conduction corresponds to the useful thermal energy. As shown in Figure 7 the electrical power and the heat by conduction in the PV module vary, based on $R_{s e}$, mainly due to the power dissipation.

This indicates that, if the $R_{s e}$ is selected, $\mathrm{PV}$ will only deliver electrical power and thermal power under a given condition. For example, it is observed in Figure 12 that when $R_{s e}$ is $0 \Omega$, the electrical and thermal power at the steady-state is $2835 \mathrm{~W}$ and $450 \mathrm{~W}$, respectively. The electrical power is prioritised. While in Figure 13, when $R_{s e}$ is to set $20 \Omega$, the electrical and thermal power at the steady-state is $831 \mathrm{~W}$ and $1150 \mathrm{~W}$, respectively. The electrical power is degraded to prioritise the useful thermal energy. However, the $R_{s e}$ is used to control the energy of the PV module. These findings are consistent with similar previous studies [42, 43.

\section{Conclusion}

The design and modelling of a PV cell system were carried out in MATLAB/Simulink to validate the heat transfer occurring in the PV cell model. The PV cell's output is partially converted into useful thermal energy (the internal heat generation) for domestic hot water supply and space heating. A change of $R_{s e}$ might be an effective method of controlling the amount 


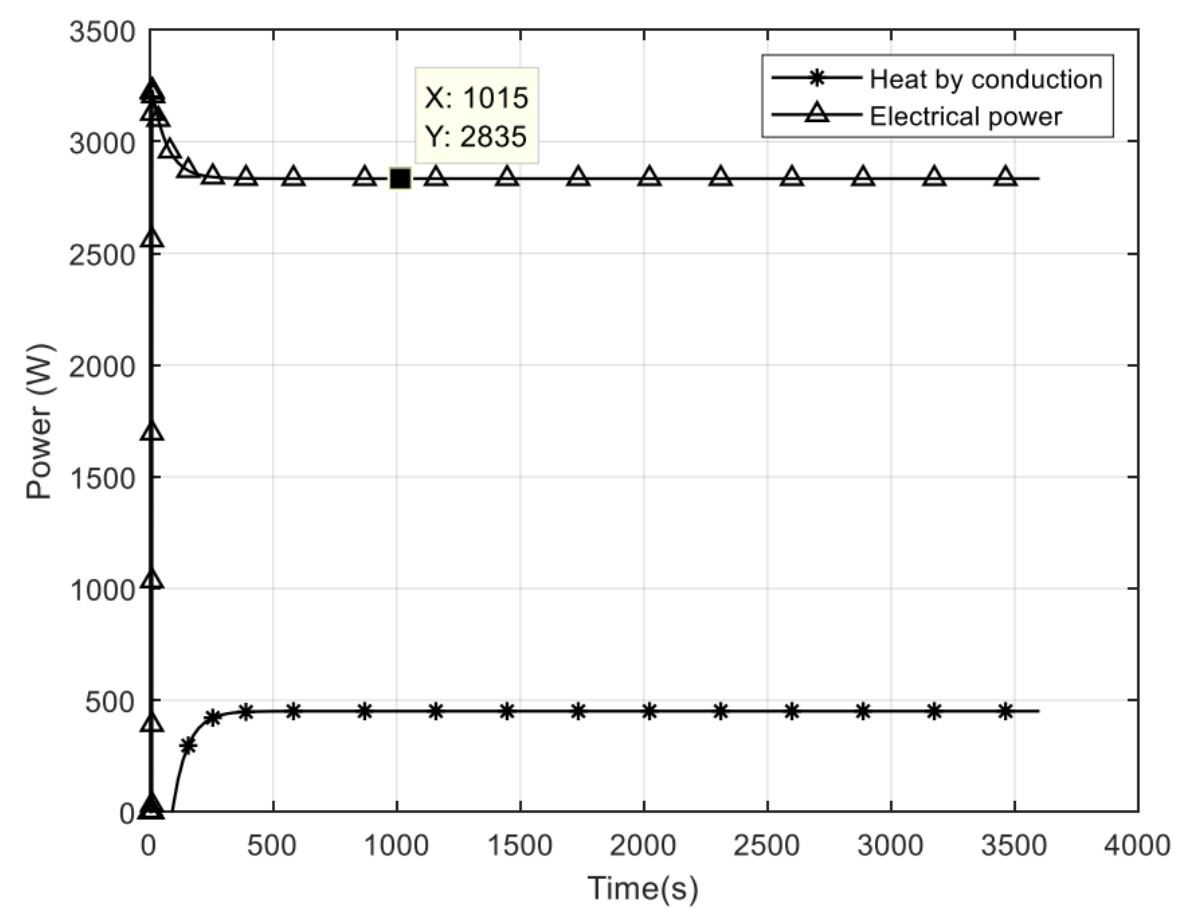

Figure 12. Generated powers from PV cell when $R_{s e}$ is $0 \Omega$.

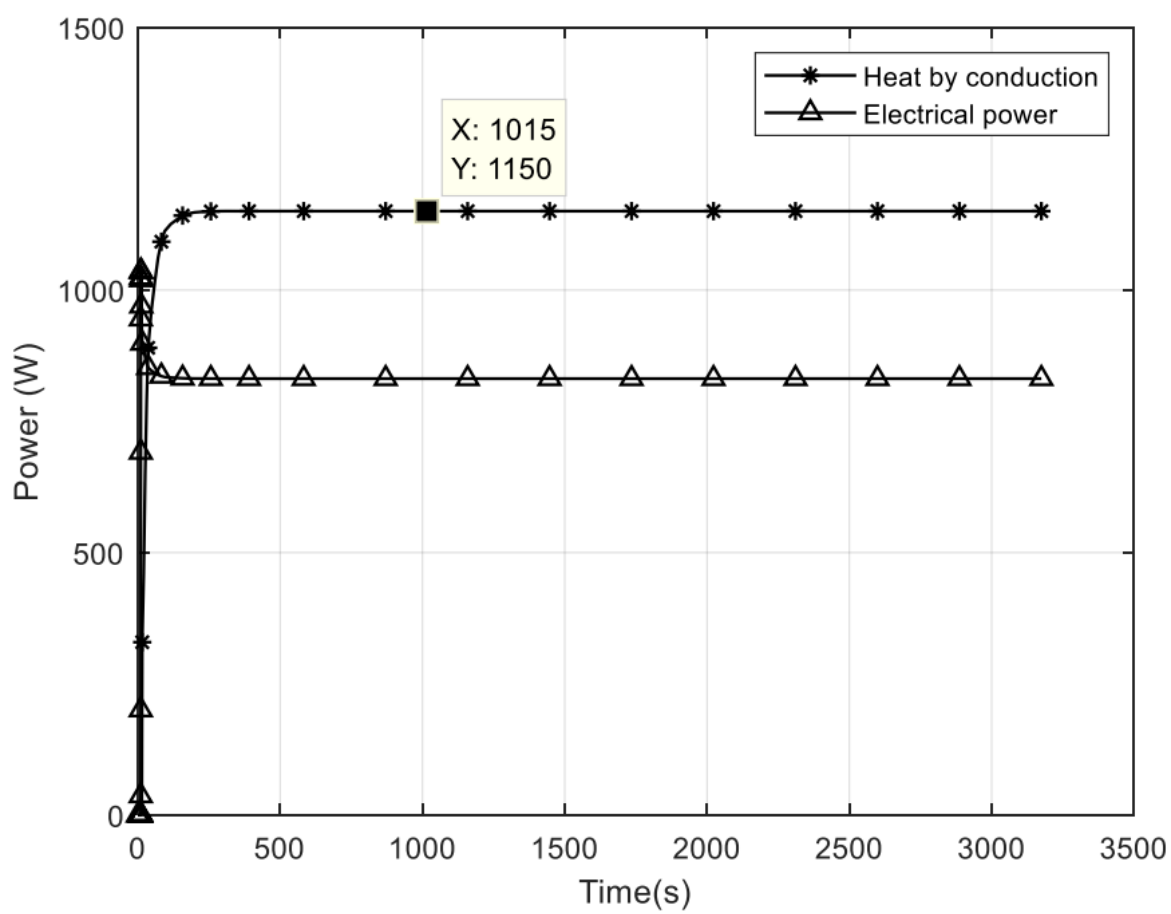

FiguRE 13. Generated powers from PV cell when $R_{\text {se }}$ is $20 \Omega$. 
of thermal and electrical energy from the PV cell. The technique is determined by a linear regression equation curve to model the behavioural patterns of various types of power (thermal and electrical) as a function of $R_{s e}$.

These findings are particularly useful for household water-heating systems. $R_{s e}$ may be adjusted to produce supplementary heat while the fluid carries the produced heat to the load.

A further research will develop a model that incorporates the absorber pipe affixed at the rear of the PV cell model, all together linked to a hydraulic pump and storage device. The optimisation technique that modulates the ratio of thermal to the electrical energy generated from the PV cell may be used to optimise the combined PV/T system's performance.

\section{REFERENCES}

[1] N. El Bassam, P. Maegaard, M. L. Schlichting. Chapter six - Energy basics, resources, global contribution and applications. In Distributed Renewable Energies for Off-Grid Communities, pp. 85 - 90. Elsevier, 2013. https://doi.org/10.1016/B978-0-12-397178-4.00006-2

[2] W.-C. Lu. Greenhouse gas emissions, energy consumption and economic growth: a panel cointegration analysis for 16 Asian countries. International journal of environmental research and public health 14(11):1436, 2017. https://doi.org/10.3390/ijerph14111436.

[3] A. A. A. Moussavou, M. Adonis, A. K. Raji. Microgrid energy management system control strategy. In 2015 International Conference on the Industrial and Commercial Use of Energy (ICUE), pp. 147 - 154. 2015. https://doi.org/10.1109/ICUE.2015.7280261.

[4] A. N. Nunes. Energy changes in Portugal. An overview of the last century. Méditerranée Revue géographique des pays méditerranéens/Journal of Mediterranean geography (130), 2018. https://doi.org/10.4000/mediterranee.10113

[5] A. Stocker, A. Großmann, R. Madlener, M. I. Wolter. Sustainable energy development in Austria until 2020: Insights from applying the integrated model "e3. at". Energy policy 39(10):6082 - 6099, 2011. https://doi.org/10.1016/j.enpol.2011.07.009.

[6] D. Banks, J. Schäffler. The potential contribution of renewable energy in South Africa. Sustainable Energy \& Climate Change Project, 2006.

[7] A. Chel, G. Kaushik. Renewable energy technologies for sustainable development of energy efficient building. Alexandria Engineering Journal 57(2):655 - 669, 2018. https://doi.org/10.1016/j.aej.2017.02.027

[8] B. Bøhm. Production and distribution of domestic hot water in selected Danish apartment buildings and institutions. Analysis of consumption, energy efficiency and the significance for energy design requirements of buildings. Energy Conversion and Management 67:152 159, 2013. https://doi.org/10.1016/j.enconman.2012.11.002.

[9] G. Y. Chuang, Y. M. Ferng. Experimentally investigating the thermal mixing and thermal stripping characteristics in a T-junction. Applied Thermal
Engineering 113:1585 - 1595, 2017. https://doi.org/10.1016/j.applthermaleng.2016.10.157

[10] R. Tunstall, D. Laurence, R. Prosser, A. Skillen. Large eddy simulation of a T-Junction with upstream elbow: The role of Dean vortices in thermal fatigue. Applied Thermal Engineering 107:672 - 680, 2016. https://doi.org/10.1016/j.applthermaleng.2016.07.011

[11] J.-H. Kim, J.-T. Kim. The experimental performance of an unglazed PVT collector with two different absorber types. International Journal of Photoenergy 2012, 2012. https://doi.org/10.1155/2012/312168

[12] H. A. Zondag. Flat-plate PV-Thermal collectors and systems: A review. Renewable and Sustainable Energy Reviews 12(4):891 - 959, 2008.

https://doi.org/10.1016/j.rser.2005.12.012

[13] Z. Xu, C. Kleinstreuer. Concentration photovoltaic-thermal energy co-generation system using nanofluids for cooling and heating. Energy Conversion and Management 87:504 - 512, 2014. https://doi.org/10.1016/j.enconman.2014.07.047.

[14] A. H. A. Al-Waeli, M. T. Chaichan, H. A. Kazem, et al. Numerical study on the effect of operating nanofluids of photovoltaic thermal system $(\mathrm{PV} / \mathrm{T})$ on the convective heat transfer. Case studies in thermal engineering 12:405 - 413, 2018. https://doi.org/10.1016/j.csite.2018.05.011.

[15] P. K. Nagarajan, J. Subramani, S. Suyambazhahan, R. Sathyamurthy. Nanofluids for solar collector applications: A review. Energy Procedia 61:2416 - 2434, 2014. https://doi.org/10.1016/j.egypro.2014.12.017

[16] K. Terashima, H. Sato, T. Ikaga. Development of an environmentally friendly PV/T solar panel. Solar Energy 199:510 - 520, 2020. https://doi.org/10.1016/j.solener.2020.02.051.

[17] R. Braun, M. Haag, J. Stave, et al. System design and feasibility of trigeneration systems with hybrid photovoltaic-thermal (PVT) collectors for zero energy office buildings in different climates. Solar Energy 196:39 - 48, 2020. https://doi.org/10.1016/j.solener.2019.12.005

[18] O. Dupre, B. Niesen, S. De Wolf, C. Ballif. Field performance versus standard test condition efficiency of tandem solar cells and the singular case of perovskites/silicon devices. The journal of physical chemistry letters 9(2):446 - 458, 2018. https://doi.org/10.1021/acs.jpclett.7b02277.

[19] L. Hernández-Callejo, S. Gallardo-Saavedra, V. Alonso-Gómez. A review of photovoltaic systems: Design, operation and maintenance. Solar Energy 188:426 - 440, 2019 https://doi.org/10.1016/j.solener.2019.06.017

[20] V. Perraki, P. Kounavis. Effect of temperature and radiation on the parameters of photovoltaic modules. Journal of Renewable and Sustainable Energy 8(1):013102, 2016. https://doi.org/10.1063/1.4939561

[21] M. R. Maghami, H. Hizam, C. Gomes, et al. Power loss due to soiling on solar panel: A review. Renewable and Sustainable Energy Reviews 59:1307 - 1316, 2016. https://doi.org/10.1016/j.rser.2016.01.044. 
[22] J. Page. Chapter IIA-1 - The Role of Solar-Radiation Climatology in the Design of Photovoltaic Systems. In Practical Handbook of Photovoltaics, pp. $573-643$. Academic Press, Boston, second edition edn., 2012. https://doi.org/10.1016/B978-0-12-385934-1.00017-9

[23] T. Markvart, L. Castañer (eds.). Practical Handbook of Photovoltaics: Fundamentals and Applications. Elsevier, 2013.

https://doi.org/10.1016/B978-1-85617-390-2.X5000-4.

[24] C. Xiao, X. Yu, D. Yang, D. Que. Impact of solar irradiance intensity and temperature on the performance of compensated crystalline silicon solar cells. Solar Energy Materials and Solar Cells 128:427 434, 2014. https://doi.org/10.1016/j.solmat.2014.06.018

[25] J.-C. Wang, Y.-L. Su, J.-C. Shieh, J.-A. Jiang. High-accuracy maximum power point estimation for photovoltaic arrays. Solar Energy Materials and Solar Cells 95(3):843 - 851, 2011. https://doi.org/10.1016/j.solmat.2010.10.032.

[26] A. R. Jha. Solar Cell Technology and Applications. Auerbach Publications, 2009. https://doi.org/10.1201/9781420081787.

[27] F. Fertig, S. Rein, M. Schubert, W. Warta. Impact of junction breakdown in multi-crystalline silicon solar cells on hot spot formation and module performance. In 26th European Photovoltaic Solar Energy Conference and Exhibition, pp. 1168 - 1178. 2011. https://doi.org/10.4229/26thEUPVSEC2011-2DO.3.1.

[28] P. Singh, N. M. Ravindra. Temperature dependence of solar cell performance - an analysis. Solar energy materials and solar cells 101:36 - 45, 2012. https://doi.org/10.1016/j.solmat.2012.02.019.

[29] J. Zaraket, T. Khalil, M. Aillerie, et al. The Effect of Electrical stress under temperature in the characteristics of PV Solar Modules. Energy Procedia 119:579 - 601, 2017. https://doi.org/10.1016/j.egypro.2017.07.083.

[30] J. C. Teo, R. H. G. Tan, V. H. Mok, et al. Impact of partial shading on the pv characteristics and the maximum power of a photovoltaic string. Energies 11(7):1860, 2018. https://doi.org/10.3390/en11071860

[31] A. J. Swart, P. E. Hertzog. Varying percentages of full uniform shading of a PV module in a controlled environment yields linear power reduction. Journal of Energy in Southern Africa 27(3):28 - 38, 2016.

[32] P. Arjyadhara, S. M. Ali, J. Chitralekha. Analysis of solar PV cell performance with changing irradiance and temperature. International Journal of Engineering and Computer Science 2(1):214 - 220, 2013.

[33] P. Löper, D. Pysch, A. Richter, et al. Analysis of the temperature dependence of the open-circuit voltage. Energy Procedia 27:135 - 142, 2012.

[34] C. H. Henry. Limiting efficiencies of ideal single and multiple energy gap terrestrial solar cells. Journal of Applied Physics 51(8):4494 - 4500, 1980. https://doi.org/10.1063/1.328272.

[35] G. Trzmiel, D. Głuchy, D. Kurz. The impact of shading on the exploitation of photovoltaic installations. Renewable Energy 153:480 - 498, 2020. https://doi.org/10.1016/j.renene.2020.02.010.
[36] A. M. Humada, F. B. Samsuri, M. Hojabria, et al. Modeling of photovoltaic solar array under different levels of partial shadow conditions. In 16th International Power Electronics and Motion Control Conference and Exposition, pp. 461 - 465. 2014. https://doi.org/10.1109/EPEPEMC.2014.6980535.

[37] F. Lu, S. Guo, T. M. Walsh, A. G. Aberle. Improved pv module performance under partial shading conditions. Energy Procedia 33:248 - 255, 2013. https://doi.org/10.1016/j.egypro.2013.05.065

[38] L. A. Kosyachenko. Solar Cells - Thin-Film Technologies, chap. Thin-Film Photovoltaics as a Mainstream of Solar Power Engineering, pp. $1-40$. IntechOpen Limited, London, 2011. https://doi.org/10.5772/39070

[39] D. Kiermasch, L. Gil-Escrig, H. J. Bolink, K. Tvingstedt. Effects of masking on open-circuit voltage and fill factor in solar cells. Joule 3(1):16 - 26, 2019. https://doi.org/10.1016/j.joule.2018.10.016

[40] H. A. Koffi, A. A. Yankson, A. F. Hughes, et al. Determination of the series resistance of a solar cell through its maximum power point. African Journal of Science, Technology, Innovation and Development 12(6):699 - 702, 2020. https://doi.org/10.1080/20421338.2020.1731073.

[41] M. Wolf, H. Rauschenbach. Series resistance effects on solar cell measurements. Advanced Energy Conversion 3(2):455 - 479, 1963. https://doi.org/10.1016/0365-1789(63)90063-8.

[42] P. G. Kale, K. K. Singh, C. Seth. Modeling effect of dust particles on performance parameters of the solar PV module. In 2019 Fifth International Conference on Electrical Energy Systems, pp. 1 - 5. 2019. https://doi.org/10.1109/ICEES.2019.8719298

[43] A. Hussain, A. Batra, R. Pachauri. An experimental study on effect of dust on power loss in solar photovoltaic module. Renewables: Wind, Water, and Solar 4(1):9, 2017. https://doi.org/10.1186/s40807-017-0043-y

[44] K. Dastoori, G. Al-Shabaan, M. Kolhe, et al. Charge measurement of dust particles on photovoltaic module. In 8th International Symposium on Advanced Topics in Electrical Engineering, pp. 1 - 4. 2013. https://doi.org/10.1109/ATEE.2013.6563411.

[45] R. Vaillon, O. Dupré, R. B. Cal, M. Calaf. Pathways for mitigating thermal losses in solar photovoltaics. Scientific reports 8:13163, 2018.

[46] M. Hammami, S. Torretti, F. Grimaccia, G. Grandi. Thermal and performance analysis of a photovoltaic module with an integrated energy storage system. Applied Sciences 7(11):1107, 2017. https://doi.org/10.3390/app7111107.

[47] R. Masoudi Nejad. A survey on performance of photovoltaic systems in iran. Iranian (Iranica) Journal of Energy \& Environment 6(2):77 - 85, 2015. https://doi.org/10.5829/idosi.ijee.2015.06.02.01

[48] J. A. Duffie, W. A. Beckman. Solar Engineering of Thermal Processes. Wiley, New York, 1991.

[49] P. Singh, N. Ravindra. Analysis of series and shunt resistance in silicon solar cells using single and double exponential models. Emerging Materials Research 1:33 - 38, 2012. https://doi.org/10.1680/emr.11.00008 